Article

\title{
Transition Metal-Modified Zirconium Phosphate Electrocatalysts for the Oxygen Evolution Reaction
}

\author{
Joel Sanchez ${ }^{1}$, Mario V. Ramos-Garcés ${ }^{2}$, Ieva Narkeviciute ${ }^{1}$, Jorge L. Colón ${ }^{2, *}$ \\ and Thomas F. Jaramillo ${ }^{2, *}$ \\ 1 Department of Chemical Engineering, Stanford University, Stanford, CA 94305, USA; \\ joelsan@stanford.edu (J.S.); ieva@stanford.edu (I.N.) \\ 2 Department of Chemistry, University of Puerto Rico-Río Piedras Campus, P.O. Box 70377, \\ San Juan, PR 00936-8377, USA; mario.ramos1@upr.edu \\ * Correspondence: jorge.colon10@upr.edu (J.L.C.); jaramillo@stanford.edu (T.F.J.); \\ Tel.: +1-787-402-2015 (J.L.C.); +1-650-353-1984 (T.F.J)
}

Academic Editor: Monica Pica

Received: 1 March 2017; Accepted: 20 April 2017; Published: 1 May 2017

\begin{abstract}
Zirconium phosphate $(\mathrm{ZrP})$, an inorganic layered nanomaterial, is currently being investigated as a catalyst support for transition metal-based electrocatalysts for the oxygen evolution reaction (OER). Two metal-modified $\mathrm{ZrP}$ catalyst systems were synthesized: metal-intercalated $\mathrm{ZrP}$ and metal-adsorbed $\mathrm{ZrP}$, each involving $\mathrm{Fe}(\mathrm{II}), \mathrm{Fe}(\mathrm{III}), \mathrm{Co}(\mathrm{II})$, and Ni(II) cations. Fourier transform infrared spectroscopy, $\mathrm{X}$-ray powder diffraction, thermogravimetric analysis, and X-ray photoelectron spectroscopy were used to characterize the composite materials and confirm the incorporation of the metal cations either between the layers or on the surface of $\mathrm{ZrP}$. Both types of metal-modified systems were examined for their catalytic activity for the OER in $0.1 \mathrm{M} \mathrm{KOH}$ solution. All metal-modified $\mathrm{ZrP}$ systems were active for the OER. Trends in activity are discussed as a function of the molar ratio in relation to the two types of catalyst systems, resulting in overpotentials for metal-adsorbed $\mathrm{ZrP}$ catalysts that were less than, or equal to, their metal-intercalated counterparts.
\end{abstract}

Keywords: zirconium phosphate; intercalation; ion exchange; catalyst support; oxygen evolution reaction; electrocatalysis; water oxidation

\section{Introduction}

The renewable, sustainable production of hydrogen could have many benefits, displacing the conventional fossil-based processes for its production and use in the fuels and chemical industry, and potentially serving as an alternative energy vector given its high gravimetric energy density and modularity of use [1]. Conventional hydrogen is produced through steam methane reforming, but hydrogen produced by water electrolysis has the potential to be $\mathrm{CO}_{2}$-emission free if the energy required is provided by renewable energy sources. Technological improvements will be needed for the cost-effectiveness of electrolysis to compete with current methods of hydrogen production [2,3]. Water electrolysis is the decomposition of water through two half-reactions of water splitting, the oxygen evolution reaction (OER) and the hydrogen evolution reaction (HER). The OER is important for many renewable energy conversion technologies, such as photoelectrochemical cells, regenerative fuel cells, and electrolyzers $[1,4,5]$. In acid systems, Ir and Ru-based oxides are common catalysts for the OER, while in alkaline environments non-precious transition metal oxides based on $\mathrm{Ni}$, $\mathrm{Fe}$, and $\mathrm{Co}$ are commonly employed [6-10]. In all cases, OER catalysts suffer from considerable overpotential losses, limiting the efficiency of hydrogen generation by water electrolysis processes [11].

To overcome these challenges and thus to facilitate the economic viability of electrolysis, the efficiencies of electrolyzer systems must be improved by addressing the kinetic overpotential 
losses associated with turning over the OER and, ideally, using catalysts based on Earth-abundant elements. Recent studies have focused on reducing the amount of precious metals in OER catalysis, using more Earth-abundant transition metals in their oxide and/or hydroxide form to catalyze the reaction [12-14]. However, as reported by recent experimental benchmarking efforts and supported by theoretical calculations, the overpotentials of state-of-the-art catalysts have plateaued close to the theoretical minimum overpotential for the OER, predicted for conventional materials, including those based on precious metals $[15,16]$. Significant research has been conducted to improve electrocatalysts through a number of general strategies, including increasing the number of active sites, increasing the intrinsic activity of each active site, and/or supporting the active material onto supports that engender improved performance [17-21]. In particular, catalyst supports have shown to play an important role in the performance and stability of catalysts for many different reactions [22-24].

In this study, the use of the zirconium phosphate ( $\mathrm{ZrP})$ type of layered inorganic compounds, as a support for water oxidation catalysts, is examined. The most extensively studied phase of $\mathrm{ZrP}$ is zirconium bis(monohydrogen orthophosphate) monohydrate $\left(\mathrm{Zr}\left(\mathrm{HPO}_{4}\right)_{2} \cdot \mathrm{H}_{2} \mathrm{O}, \alpha-\mathrm{ZrP}\right)$, a layered compound with an interlayer distance of $7.6 \AA$ and a layer thickness of $6.6 \AA$ (Figure 1A) [25]. $\alpha$ - $\mathrm{ZrP}$ has a structure in which the $\mathrm{Zr}$ atoms in each layer align nearly to a plane with bridging phosphate groups $5.3 \AA$ apart, which are located alternately above and below the metal atom plane [25]. Three oxygen atoms of the phosphate group bond to three different $\mathrm{Zr}^{4+}$ ions; six $\mathrm{O}$ atoms from different phosphate groups coordinate the $\mathrm{Zr}$ atoms forming an octahedral coordination symmetry around each $\mathrm{Zr}$ atom. These bridging phosphate groups provide an ion exchange site where the proton can be exchanged with cations and other species. The above-mentioned structure of $\alpha$-ZrP creates a small molecule-sized cavity in the interlayer region with a diameter of $2.61 \AA$, which is occupied by a water molecule [25]. For $\alpha-\mathrm{ZrP}$, the direct intercalation of small cations is possible if they are smaller than $2.61 \AA$, but for larger cations and molecules, intercalation is not significant and / or these species are exchanged at very slow rates [26-28]. A direct intercalation method that can circumvent this problem involves a highly hydrated phase of zirconium phosphate, $\mathrm{Zr}\left(\mathrm{HPO}_{4}\right)_{2} \cdot 6 \mathrm{H}_{2} \mathrm{O}, \theta-\mathrm{ZrP}$ [29]. $\theta$-ZrP maintains the $\alpha$-ZrP-type layered structure (Figure 1B), but has an interlayer distance of $10.4 \AA$ and has six water molecules per formula unit, in contrast with $\alpha-Z r P$ that only has one [30]. Figure 1C shows transmission electron micrographs of $\alpha-\mathrm{ZrP}$ nanoparticles with the characteristic hexagonal nano-platelet structure with an average diameter and thickness of $\sim 140$ and $\sim 15 \mathrm{~nm}$, respectively.

A

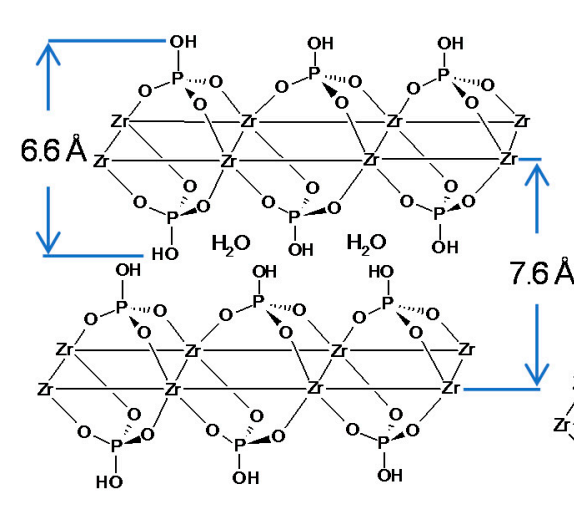

B
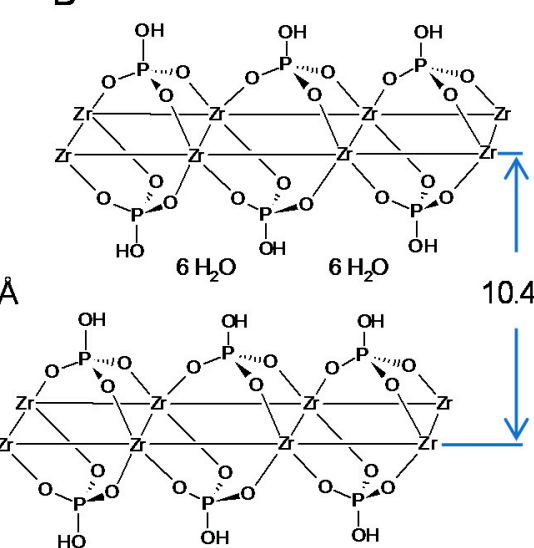

C

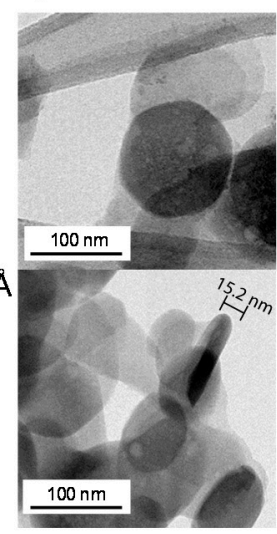

Figure 1. (A) The structure of $\alpha$-ZrP; (B) the structure of $\theta-\mathrm{ZrP}$; and (C) TEM micrographs of $\alpha$-ZrP nanoparticles where the top image shows the characteristic hexagonal shape and the bottom image shows the thickness of an $\alpha$-ZrP nanoparticle.

$\theta-\mathrm{ZrP}$ can be directly ion-exchanged with large metal complexes, producing intercalated phases useful for artificial photosynthesis schemes, amperometric biosensors, vapochromic materials, catalysis, 
and drug delivery applications [31-35]. Herein, the layered structure of $\mathrm{ZrP}$ is leveraged to support active catalysts for the OER through the ion exchange of transition metal cations. Intercalation of various metals of divalent and trivalent character (Fe(II), $\mathrm{Fe}(\mathrm{III}), \mathrm{Co}(\mathrm{II}), \mathrm{Ni}(\mathrm{II})$ ) were performed on $\theta-\mathrm{ZrP}$ at various metal to $\theta-\mathrm{ZrP}$ molar ratios. For comparison, we also investigate the same transition metal systems adsorbed onto the outer surface of $\alpha-\mathrm{ZrP}$, achieved using a similar synthesis procedure, however, due to the much tighter interlayer spacing of $\alpha-\mathrm{ZrP}$ compared to $\theta-\mathrm{ZrP}$, intercalation is not readily achieved. These two types of metal-modified $\mathrm{ZrP}$, metal-intercalated $\mathrm{ZrP}$ and metal-adsorbed $\mathrm{ZrP}$, are studied herein for their physical and chemical properties, including as OER catalysts. These oxygen evolution electrocatalyst materials were thoroughly characterized by Fourier transform infrared spectroscopy (FTIR), thermogravimetric analysis (TGA), X-ray powder diffraction (XRPD), X-ray photoelectron spectroscopy (XPS), and cyclic voltammetry. For the catalyst systems studied here in alkaline electrolyte, we generally find that the metal-adsorbed $\mathrm{ZrP}$ catalysts are more active than their intercalated counterparts, e.g., a metal-adsorbed Fe(II)-ZrP at a 10:1 Fe(II):ZrP molar ratio that requires an overpotential of $490 \mathrm{mV}$ at $10 \mathrm{~mA} / \mathrm{cm}^{2}$, while its metal-intercalated counterpart at the same molar ratio requires an overpotential of $520 \mathrm{mV}$ at $10 \mathrm{~mA} / \mathrm{cm}^{2}$.

\section{Results and Discussion}

\subsection{FTIR and TGA Analysis of Interlayer and Surface Modification of $\mathrm{ZrP}$}

Each metal-modified (metal-intercalated and metal-adsorbed) ZrP sample was created through suspensions of $\theta-\mathrm{ZrP}$ and $\alpha-\mathrm{ZrP}$ in deionized water mixed with $\mathrm{Fe}(\mathrm{II}), \mathrm{Fe}(\mathrm{III}), \mathrm{Co}(\mathrm{II})$, and $\mathrm{Ni}(\mathrm{II})$ metal salts. The loading level was controlled by varying the metal:ZrP (M:ZrP) molar ratio used in the suspension over a wide range (1:20-10:1), and the materials are referenced according to this concentration ratio throughout the article. Figure 2 shows the IR spectra of pure $\alpha-\mathrm{ZrP}$, metal-intercalated $\mathrm{ZrP}$, and metal-adsorbed $\mathrm{ZrP}$. The four characteristic $\alpha$-ZrP bands associated with lattice water were observed in the pure material. Three of them are sharp bands at $3592 \mathrm{~cm}^{-1}$, $3510 \mathrm{~cm}^{-1}$, and $1616 \mathrm{~cm}^{-1}$, while the fourth is a broad band at ca. $3141 \mathrm{~cm}^{-1}$ [36]. For the metal-intercalated samples, the two sharp bands at $3592 \mathrm{~cm}^{-1}$ and $3510 \mathrm{~cm}^{-1}$ are not observed, while the other two bands have reduced intensity compared to pure $\alpha$-ZrP. When intercalation occurs, the intercalant species will displace interlayer water molecules. For this reason, bands associated with these water vibrational modes will show reduced relative intensity in the intercalated materials; therefore, the IR data shown in Figure 2A is consistent with intercalation of the metal species into $\mathrm{ZrP}$ interlayers, as also indicated by the XRPD data (vide infra). In contrast, metal-adsorbed samples show very similar spectra to that of $\alpha-Z \mathrm{rP}$, with the sharp bands present at $3592 \mathrm{~cm}^{-1}$ and $3510 \mathrm{~cm}^{-1}$, indicating negligible intercalation, as expected.

The characteristic orthophosphate group vibrations of $\mathrm{ZrP}$ are observed in the region of ca. $1057-966 \mathrm{~cm}^{-1}$ for all samples [36]. Metal-intercalated samples show a diminished relative intensity of the shoulder at the bottom left part of the orthophosphate group vibrations at ca. $1050 \mathrm{~cm}^{-1}$, attributed to the vibration of the exchangeable proton of the phosphate group, which is lost when the proton is exchanged by intercalation via ion exchange with other species [36]. This is observed for all metal-intercalated systems, another indication of successful intercalation. For metal-adsorbed samples, this vibration is still present indicating, once again, that no intercalation is observed and, for clarity, Figure S1 shows the characteristic 3592 and $3510 \mathrm{~cm}^{-1}$ peaks for adsorbed Fe(III)-ZrP. 
A

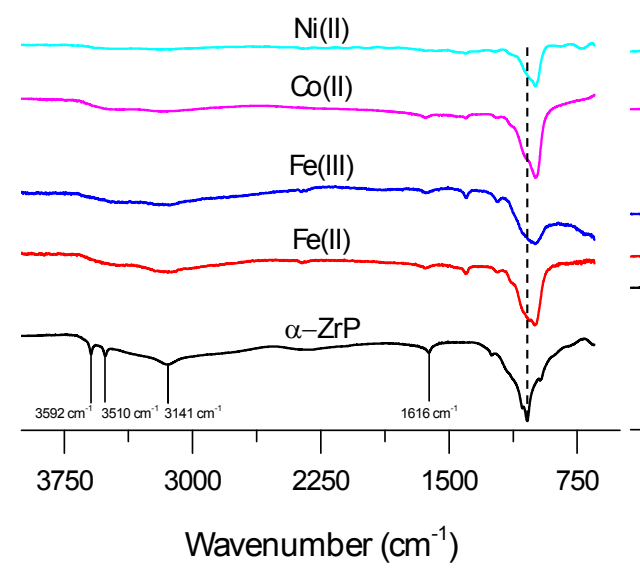

B

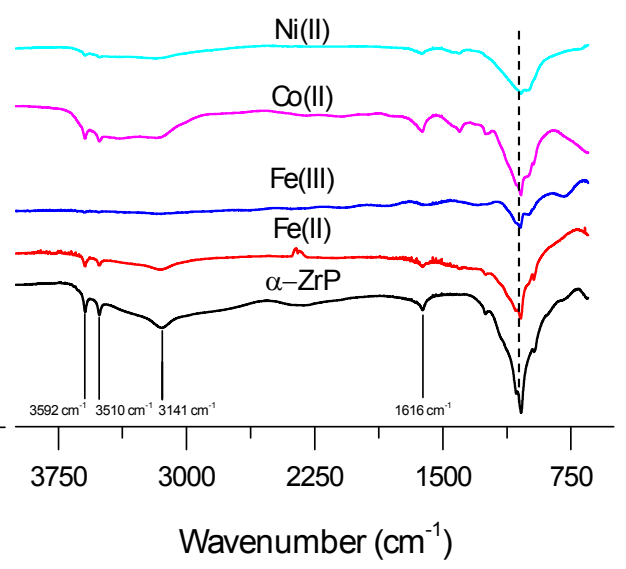

Figure 2. FTIR spectra of (A) intercalated and (B) adsorbed Fe(II), Fe(III), Co(II), and Ni(II) at 10:1 $\mathrm{M}: \mathrm{ZrP}$ ratio.

TGA was performed to further corroborate that intercalation had occurred for the metal-intercalated systems and that the metal-adsorbed catalyst had retained $\alpha-\mathrm{ZrP}$ characteristics. In the case of pure $\alpha-\mathrm{ZrP}$ (Figure 3) two weight losses are observed, dehydration of water within the interlayer below $150{ }^{\circ} \mathrm{C}$, followed by condensation to zirconium pyrophosphate at $\sim 500{ }^{\circ} \mathrm{C}$, leading to a total weight loss of $\sim 13 \%$, in agreement to previous literature results [37]. All metal-intercalated systems (Figure 3A) showed significant deviation from pure $\alpha$-ZrP, especially within the temperature range that pyrophosphate is formed. Based on thermograms for pure $\alpha-\mathrm{ZrP}$ as a reference, two regions are observed for $\mathrm{Fe}(\mathrm{II})$-intercalated systems - the dehydration of interlayer water corresponding to an $8.7 \%$ weight loss at $76{ }^{\circ} \mathrm{C}$, followed by a gradual shoulder decrease in weight loss of $4 \%$ up to $200{ }^{\circ} \mathrm{C}$. Fe(III)-intercalated systems show a $5 \%$ weight loss followed by a $3 \%$ weight loss for interlayer water dehydration and phosphate condensation, respectively. Similar results were found to those observed in previous studies for TGA thermograms involving intercalated $\mathrm{Co}$ (II) and $\mathrm{Ni}$ (II) $\mathrm{ZrP}$ systems [38]. Both $\mathrm{Co}$ (II) and Ni(II)-ZrP lose interlayer water below $150{ }^{\circ} \mathrm{C}$ for weight losses of $\sim 12 \%$ and $10 \%$, respectively. Since divalent and trivalent transition metal cations are highly hydrated in their intercalated form [39]; previously-reported reflectance and Extended X-ray Absorption Fine Structure (EXAFS) spectra show that $\mathrm{Co}(\mathrm{II})$ - and $\mathrm{Ni}(\mathrm{II})$-exchanged $\mathrm{ZrP}$ at room temperature are octahedrally coordinated with water $[40,41]$. The $3 \%$ weight loss between 200 and $300{ }^{\circ} \mathrm{C}$ for $\mathrm{Co}(\mathrm{II})-\mathrm{ZrP}$ corresponds to loss of metal coordinated waters, and the loss of structural water due to decomposition of the phosphate groups is evident between temperatures of 350 to $500{ }^{\circ} \mathrm{C}$ [38]. For Ni(II)-intercalated samples, the loss of coordinated waters between $250{ }^{\circ} \mathrm{C}$ and $300{ }^{\circ} \mathrm{C}$ results in a $5 \%$ weight loss, and decomposition of the phosphate groups to form pyrophosphate occurs between $350{ }^{\circ} \mathrm{C}$ and $500{ }^{\circ} \mathrm{C}[38,42]$. $\mathrm{Ni}(\mathrm{II})-\mathrm{ZrP}$ samples are more stable than $\mathrm{Co}(\mathrm{II})-\mathrm{ZrP}$, as expected due to their higher ligand field stabilization energy [43]. Conversely, for all adsorbed cases (Figure 3B), their respective thermograms were similar to $\alpha$-ZrP indicating that no major modification of the interlayer had occurred except for a reduction in weight loss for pyrophosphate, showing that the surface phosphates had undergone modification by the metal cations. All FTIR spectra and TGA thermograms are within expected results for our $\mathrm{ZrP}$ systems and further substantiate that intercalated and adsorbed systems were created as planned. 
A
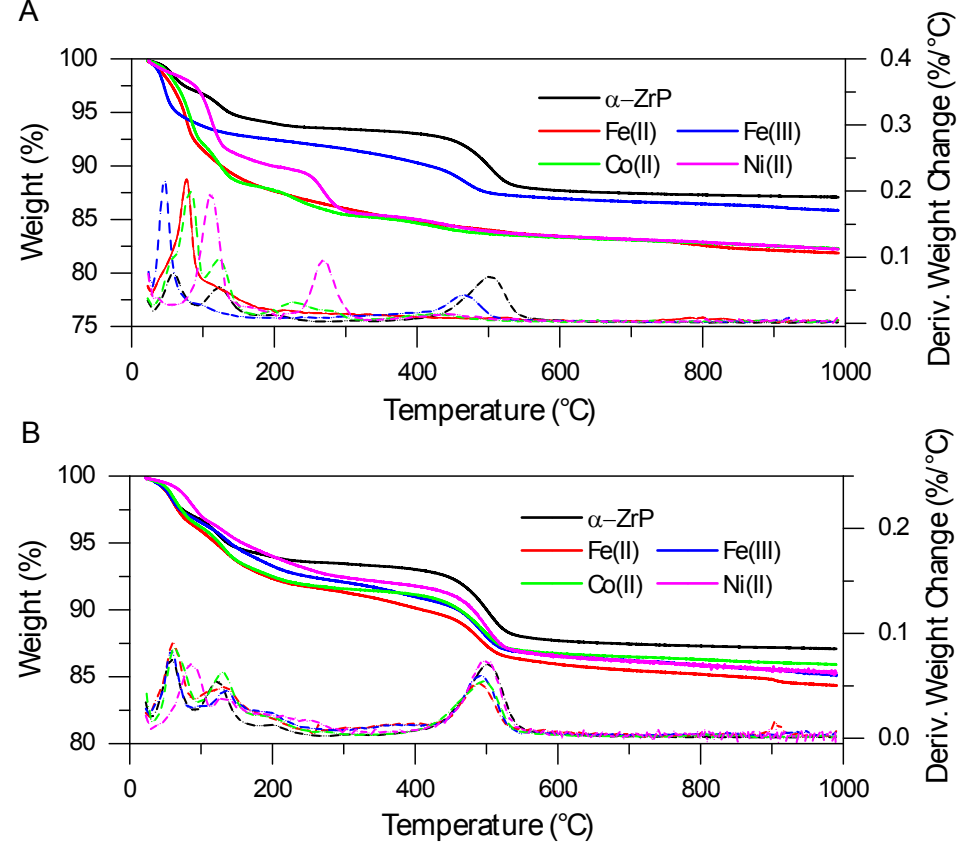

Figure 3. TGA thermograms of (A) intercalated and (B) adsorbed $\mathrm{Fe}(\mathrm{II}), \mathrm{Fe}(\mathrm{III}), \mathrm{Co}(\mathrm{II})$, and $\mathrm{Ni}(\mathrm{II})$ at a 10:1 M:ZrP ratio. Solid lines and dashed lines correspond to normalized weight and the first derivative of weight change with respect to temperature, respectively.

\subsection{XRPD Interlayer Expansion Analysis of Metal-Modified $\mathrm{ZrP}$}

To assess possible interlayer expansion of $\mathrm{ZrP}$ sheets as a function of transition metal and cation valence, $\mathrm{X}$-ray powder diffraction (XRPD) measurements were performed for dried metal-modified $\mathrm{ZrP}$ systems. If pure $\theta-\mathrm{ZrP}$ is dried, dehydration converts it to $\alpha-\mathrm{ZrP}$; therefore, all samples are referenced to the $\alpha-\mathrm{ZrP}(002)$ diffraction peak at $2 \theta=11.5^{\circ}$, corresponding to an interlayer distance of $7.6 \AA$ [44]. As described in the literature, an intercalation reaction can occur in a stepwise fashion depending on the intercalation energy threshold of the intercalants [45]. During this process, one of three possible patterns can be observed by XRPD for metal-modified ZrP; either (i) a pattern with a peak corresponding to a larger interlayer spacing at lower $2 \theta$ values than $11.5^{\circ}$ indicating that metal cations were introduced into the interlayer; (ii) a pattern with two distinct peaks-one at approximately $2 \theta=11.5^{\circ}$ and one that appears at lower $2 \theta$ values than the reference peak indicating that a mixed phase is present; and (iii) a pattern with no change in the reference peak, indicating that the cation species is adsorbed on the outer surface of the layered structure rather than being intercalated [44]. Below, the XRPD analysis for all metal-modified ZrP systems is presented.

Figure $4 \mathrm{~A}$ shows the XRPD of pure $\alpha-\mathrm{ZrP}$ and metal-intercalated $\mathrm{ZrP}$ for Fe(II), $\mathrm{Fe}(\mathrm{III}), \mathrm{Co}(\mathrm{II})$, and $\mathrm{Ni}(\mathrm{II})$, at $\mathrm{M}: \mathrm{ZrP}$ molar ratios ranging from 1:20 to 10:1. A stepwise process is expected as a function of intercalant solution molarity; the intercalation reaction initiates from the edges of the particle and proceeds by diffusion of the metal cations towards the interior of the interlayer sheets [37]. The diffraction patterns for all four metal cation systems show a shift of the first diffraction peak towards lower $2 \theta$ values compared to the (002) peak of pure $\alpha-\mathrm{ZrP}$, indicating that new intercalated phases with expanded interlayer distance $(>7.6 \AA)$ were obtained, even for the lowest M:ZrP molar ratio of 1:20. Increasing the M:ZrP molar ratios to 1:10 and 1:3 results in further broadening and shifting of the peak across all samples, indicating a more mixed phase is present, and that the layered structure has not achieved its maximum cation loading within the interlayer. At the highest loadings (i.e., 1:1 to $10: 1$ molar ratios), the original peak at $2 \theta=11.5^{\circ}$ has disappeared, with a new peak emerging at significantly lower values of $2 \theta$, reaching a final value indicative of the maximum interlayer distance for that particular metal cation intercalated within ZrP. Figure S2 shows additional data regarding the 
(020) and (31 $)$ reflections of these catalyst systems, further confirming that the intercalated products for the metal-intercalated systems retained the layered structure of $\mathrm{ZrP}$.

As expected for an ion-exchange reaction, Figure 4B shows that intercalated samples with divalent cations (i.e., $\mathrm{Fe}(\mathrm{II}))$ underwent a much larger interlayer spacing transformation than trivalent cations (i.e., $\mathrm{Fe}(\mathrm{III})$ ), with an average increase of 2.0 and $0.6 \AA$, respectively. During intercalation, higher valence species induce a strong electrostatic interaction with the anionic interlayers, which mitigates interlayer expansion [46]. Figure 4B also shows that, for the case of the metal-adsorbed $\mathrm{ZrP}$ systems, their respective interlayer spacing were unchanged and remained equal to that of $\alpha-\operatorname{ZrP}(7.6 \AA)$ at 1:1-1:10 molar ratios, conclusively showing that, for these particular materials, the metal is adsorbed on the surface and not intercalated. Figure S3 shows the XRPD data for these systems, revealing that the adsorbed species have an identical XRPD pattern to pure $\alpha-\mathrm{ZrP}$ confirming that the characteristic $\alpha$-like layered structure is still intact for the metal-adsorbed system. As the catalysts were not processed further (e.g., with heat treatments), the form of the metal resulting on the surface of $\mathrm{ZrP}$ is amorphous and, as expected, no diffraction corresponding to those metals is observed by XRPD. We note that it is possible that the metal-intercalated $\mathrm{ZrP}$ systems might also contain adsorbed metals on their surfaces (that are also not observable by XRPD) in addition to those within the layers.
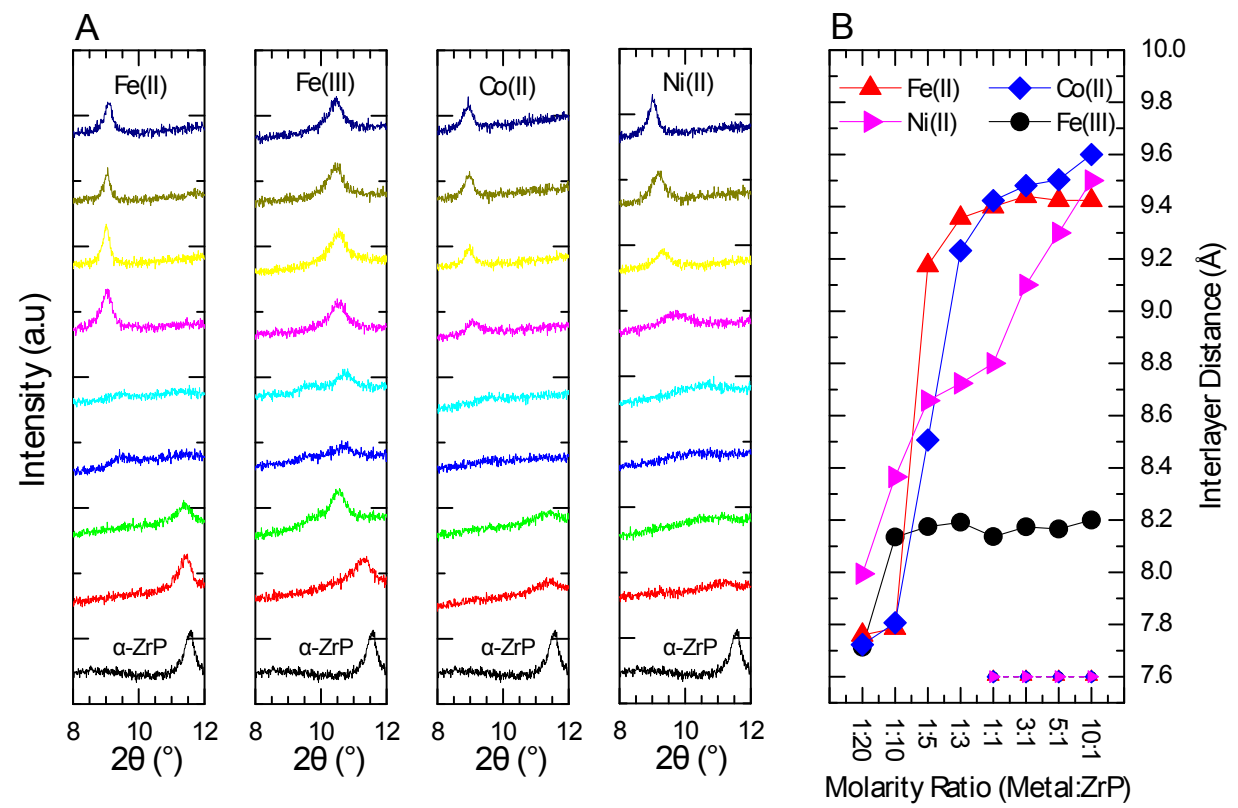

Figure 4. (A) XRPD patterns for Fe(II), Fe(III), Co(II), and Ni(II)-intercalated ZrP at (from top to bottom) 10:1, 5:1, 3:1, 1:1, 1:3, 1:5, 1:10, and 1:20 M:ZrP molar ratios. The bottom diffraction pattern in all frames is that of pure $\alpha-\mathrm{ZrP}$. (B) Interlayer distance as a function of M:ZrP molar ratio for the various metal-intercalated $\mathrm{ZrP}$ materials. Metal-adsorbed systems are represented as dashed lines which have an exact interlayer spacing as pure $\alpha-\mathrm{ZrP}$ indicating that metal intercalation did not occur.

\subsection{XPS Analysis of Metal Loading and Chemical Composition of Metal-Modified ZrP}

To quantify the relative amounts of cations for the metal-modified $\mathrm{ZrP}$ systems, and to investigate the chemical nature of the metal, XPS spectra were obtained for metal-modified catalysts at 10:1 M:ZrP molar ratios for all four metals and at 1:1 to 10:1 molar ratios for the $\mathrm{Fe}(\mathrm{II})-\mathrm{ZrP}$ system. Figure 5 shows XPS atomic concentrations of intercalated and adsorbed M(II/III):ZrP at high loadings. As expected, due to the uptake of metal cations within the much larger area of the interlayers of $\mathrm{ZrP}$ rather than solely on the surface in the adsorbed case, XPS high-resolution scans show that intercalated ZrP systems have higher atomic metal content when compared to adsorbed systems at similar M:ZrP ratios. As depicted in Figure 6, the characteristic peaks for $\mathrm{Zr}$, $\mathrm{P}$, and the respective metals were present for all samples. 
The XPS spectra of Fe(II) samples in Figure 5A show the Fe $2 \mathrm{p}_{3 / 2}$ and Fe $2 \mathrm{p}_{1 / 2}$ peaks for the intercalated samples at $712.4 \mathrm{eV}$ and $725.8 \mathrm{eV}$, respectively, and for the adsorbed samples at $713.0 \mathrm{eV}$ and $726.6 \mathrm{eV}$, respectively. The peak positions of $\mathrm{Fe}(\mathrm{II}) 2 \mathrm{p}_{3 / 2}$ and $2 \mathrm{p}_{1 / 2}$ peaks in oxide materials are expected at approximately $709.0 \mathrm{eV}$ and $723.0 \mathrm{eV}$, respectively [47]. Figure 6A shows that for both the $\mathrm{Fe}(\mathrm{II})$-intercalated and the $\mathrm{Fe}$ (II)-adsorbed systems, higher binding energies are observed, which might correspond to partial oxidation of the Fe(II) species upon $\mathrm{ZrP}$ incorporation due to interactions with the phosphate groups; the $\mathrm{Fe} 2 \mathrm{p}_{3 / 2}$ peak in $\mathrm{FePO}_{4}$ is expected at $712.8 \mathrm{eV}$ [48]. On the other hand, the $\mathrm{Fe}(\mathrm{III})$-intercalated sample, Figure $5 \mathrm{~A}$ shows the $\mathrm{Fe} 2 \mathrm{p}_{3 / 2}$ peak at $711.6 \mathrm{eV}$, which is more consistent with previously-reported values expected for Fe(III) oxides, which generally exhibit the Fe $2 p_{3 / 2}$ peak between 710.6 and $711.2 \mathrm{eV}$ [47].

A

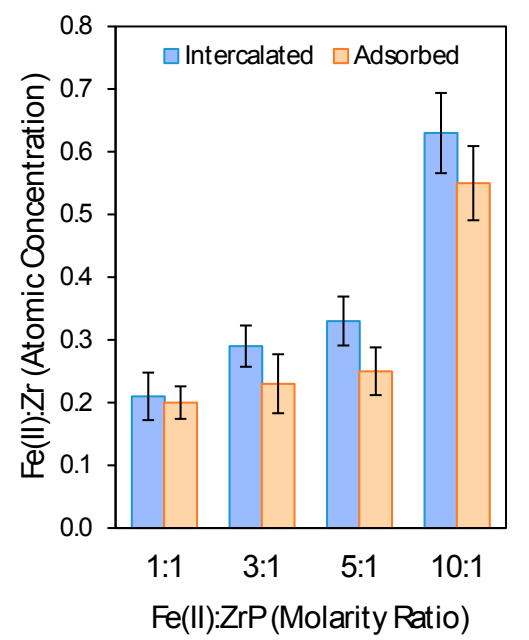

B

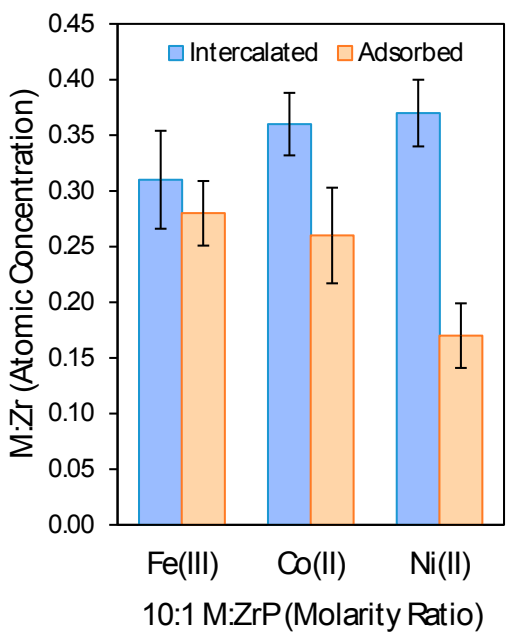

Figure 5. (A) Atomic concentration Fe:Zr ratios for metal-modified 1:1-10:1 Fe(II):ZrP molar ratio catalysts. (B) Atomic concentration M:Zr ratios for Fe(III), Co(II), and Ni(II) metal-modified 10:1 M:ZrP molar ratio catalysts.

Deconvolution of the XPS spectra for $\mathrm{Co}(\mathrm{II})$ and $\mathrm{Ni}(\mathrm{II})$ is challenging due to the small shifts in the binding energy for the (II) and (III) metal oxidation states and the broad satellite peaks [49,50]. For the Co(II) sample, Figure 6 A shows a Co $2 p$ XPS spectrum with $2 p_{3 / 2}$ and $2 p_{1 / 2}$ peaks with characteristic satellite peaks, similar to those seen in other cobalt-based zirconium phosphate catalysts, but at higher binding energies, suggesting a partial oxidation of the Co species, containing both $\mathrm{Co}(\mathrm{II})$ and $\mathrm{Co}$ (III) characteristics [51]. For the Ni(II)-ZrP, Figure 6A shows a Ni $2 p$ XPS spectrum with $2 p_{3 / 2}$ and $2 p_{1 / 2}$ peaks with satellite peaks, as well. The positions of the $2 p_{3 / 2}$ and $2 p_{1 / 2}$ peaks lie in between that of nickel oxide and nickel phosphate potentially elucidating that $\mathrm{Ni}$ cations are strongly interacting with both oxygen and phosphorus atoms in the $\mathrm{ZrP}[50,52]$.

Figure $6 \mathrm{~B}$ shows the $\mathrm{Zr} 3 \mathrm{~d}_{5 / 2}$ and $3 \mathrm{~d}_{3 / 2}$ peaks and the $\mathrm{P} 2 \mathrm{~s}$ peak for both intercalated and adsorbed samples, for the 10:1 Fe(II)-ZrP sample. In addition, Figure $6 \mathrm{C}$ shows the $\mathrm{P} 2 \mathrm{p}_{3 / 2}$ and $2 \mathrm{p}_{1 / 2}$ peaks which overlap and are, therefore, observed as a single, broad peak. For intercalated samples (blue traces), the binding energies observed for $\mathrm{Zr}$ and $\mathrm{P}$ are similar to those previously reported.

Previous reports of XPS results for modified ZrP systems have shown that intercalants can modify the polarization of both $\mathrm{Zr}$ and $\mathrm{P}$ atoms and, as a result, vary their respective binding energies when compared to pristine $\alpha-\mathrm{ZrP}[53,54]$. For the adsorbed 10:1 Fe(II)-ZrP sample, two Zr species are observed, a doublet with peaks of lower intensity, but higher binding energy (red traces), and another doublet with binding energy as reported in the literature for $\alpha-\operatorname{ZrP}$ (black traces). The high-resolution scans for the $\mathrm{Zr} 3 \mathrm{~d}$ region in $\mathrm{M}: \mathrm{Zr}$ samples show an increase in binding energy compared to that of $\alpha-\mathrm{ZrP}$, which indicates an increase in the polarization of the $\mathrm{Zr}$ atoms in the adsorbed samples due to interactions with the metal species. Similar results are seen for the $\mathrm{P} 2 \mathrm{p}_{3 / 2}$ and $2 \mathrm{p}_{1 / 2}$ binding energy 
region, where the polarization also produces a shift to increased binding energy compared to the values in $\alpha-Z r P$. The presence of this polarization on the $\mathrm{Zr}$ and $\mathrm{P}$ atoms is more pronounced on the metal-adsorbed $\mathrm{ZrP}$ samples because the metal concentration on the surface of $\mathrm{ZrP}$ is higher than the metal-intercalated ZrP and, hence, the surface sensitivity of XPS can detect this binding energy shift.

While the XPS measurements help to inform the chemical state of the metal-modified ZrP systems, we note that changes are expected from their dry powder form to that in an electrochemical environment, held at the oxidative potentials needed for water oxidation in an alkaline solution.
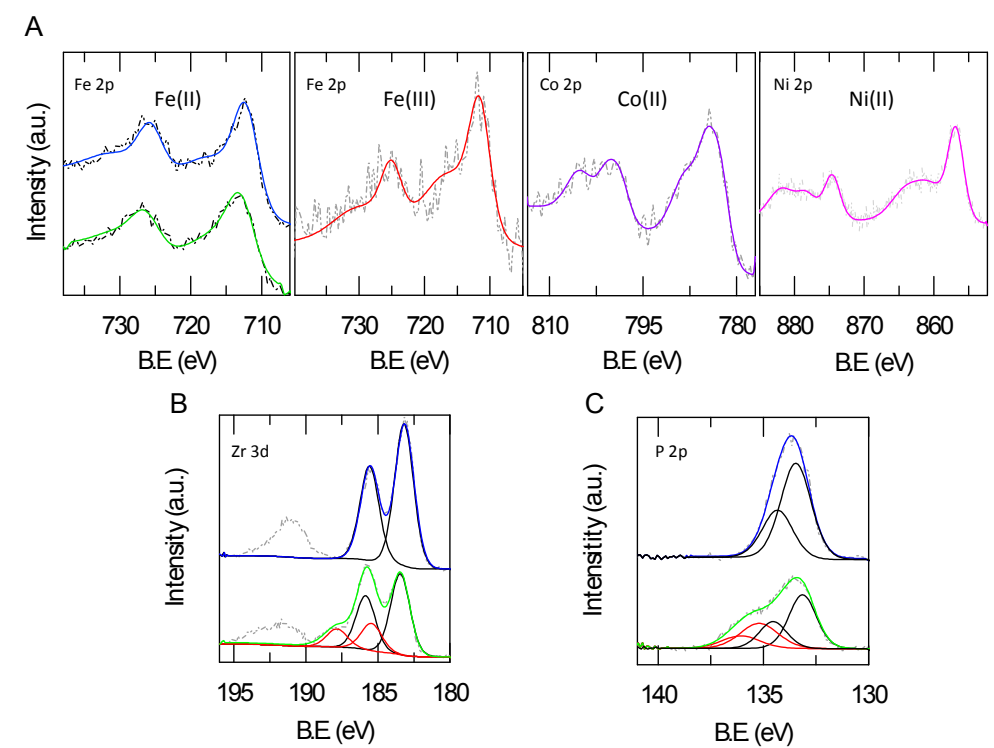

Figure 6. (A) XPS spectra for Fe(II), Fe(III), Co(II), and Ni(II) ZrP systems. Blue and green curves in Fe(II) panel represent the 10:1 M:ZrP intercalated and adsorbed systems, respectively, while intercalated 10:1 M:ZrP systems are represented in the Fe(III), Co(II), and Ni(II) panels. (B) XPS spectra for Zr 3d and (C) P 2p where blue and green curves represent intercalated and adsorbed systems, respectively, from 10:1 Fe(II):ZrP.

\subsection{Electrochemical Studies of Metal-ModifiedZrP}

To study the electrocatalytic activity of metal-modified ZrP systems for the OER, cyclic voltammetry $(\mathrm{CV})$ measurements were performed in a three-electrode rotating disk electrode (RDE) configuration with a $0.1 \mathrm{M} \mathrm{KOH}$ electrolyte. To make the working electrode, the metal-modified $\mathrm{ZrP}$ catalysts were mixed with carbon black in a water-based solution and deposited onto a glassy carbon disk. One figure of merit conventionally used to describe OER catalyst performance is the overpotential necessary to reach a current density of $10 \mathrm{~mA} / \mathrm{cm}^{2}$ [15]. Figure 7A,B show cyclic voltammograms for the highest performance metal-modified $\mathrm{ZrP}$ system with either Fe(II) adsorbed or intercalated, while the other systems can be found in Figure S4. For reference, pure $\alpha-\mathrm{ZrP}$ loaded onto carbon black shows only moderate activity for the OER, unable to achieve $10 \mathrm{~mA} / \mathrm{cm}^{2}$ even at high oxidative potentials, which is comparable to other Zr-based systems [55]. Once metal cations are ion exchanged into and/or supported onto $\mathrm{ZrP}$, an active OER catalyst is produced for both metal-modified $\mathrm{ZrP}$ systems at various M:ZrP ratios. Adsorbed $\mathrm{Fe}(\mathrm{II})-\mathrm{ZrP}$ shows a gradual increase in performance as the $\mathrm{M}: \mathrm{ZrP}$ concentration increases and similar results are observed for the intercalated case. As shown in Figure 5, higher metal content is achieved at higher M:ZrP molar ratios for both systems; therefore, it is likely that this gradual increase in activity can be attributed to higher atomic concentrations. The adsorbed 10:1 Fe(II):ZrP molar ratio exhibits the highest OER performance of all the systems investigated herein, requiring an overpotential of $490 \mathrm{mV}$ at $10 \mathrm{~mA} / \mathrm{cm}^{2}$ with a $0.55: 1 \mathrm{Fe}: \mathrm{Zr}$ atomic ratio, as determined by XPS. For comparison, the metal-intercalated equivalent system of 10:1 Fe(II): 
$\mathrm{ZrP}$ (with a higher Fe:Zr atomic ratio of 0.63:1) requires a higher overpotential of $524 \mathrm{mV}$, suggesting that the metal intercalated within $\mathrm{ZrP}$ may not be electrochemically accessible for water oxidation.

Figure 7C shows electrochemical data comparing the other metal-modified ZrP systems. All metal-modified systems are catalytically active, requiring between 0.5 and $0.7 \mathrm{~V}$ of overpotential to reach $10 \mathrm{~mA} / \mathrm{cm}^{2}$, depending on the choice of the metal cation, the M:ZrP molar ratio used during synthesis, and whether the metal was intercalated into, or adsorbed onto, ZrP. In general, lower overpotentials are observed for the higher M:ZrP molar ratios, ascribed to higher metal loadings. For the $\mathrm{Fe}(\mathrm{II}): \mathrm{ZrP}$ and $\mathrm{Ni}(\mathrm{II}): \mathrm{ZrP}$ catalysts, the intercalated systems consistently require higher overpotentials versus their adsorbed counterparts, e.g., by $34 \mathrm{mV}$ and $88 \mathrm{mV}$, respectively, at a $\mathrm{M}: \mathrm{ZrP}$ ratio of 10:1. A less pronounced difference in activity for the two types of metal-modification was observed for the cases of $\mathrm{Fe}(\mathrm{III}): \mathrm{ZrP}$ and $\mathrm{Co}(\mathrm{II}): \mathrm{ZrP}$. Given that, in general, OER activities for the metal-adsorbed $\mathrm{ZrP}$ catalysts are greater than or equal to those of their metal-intercalated counterparts at the same loading, it is likely that the OER is dominated by catalysis on the outer surface of the $\mathrm{ZrP}$ supported metal-based systems rather than within the layers, which may be limited by mass transport.
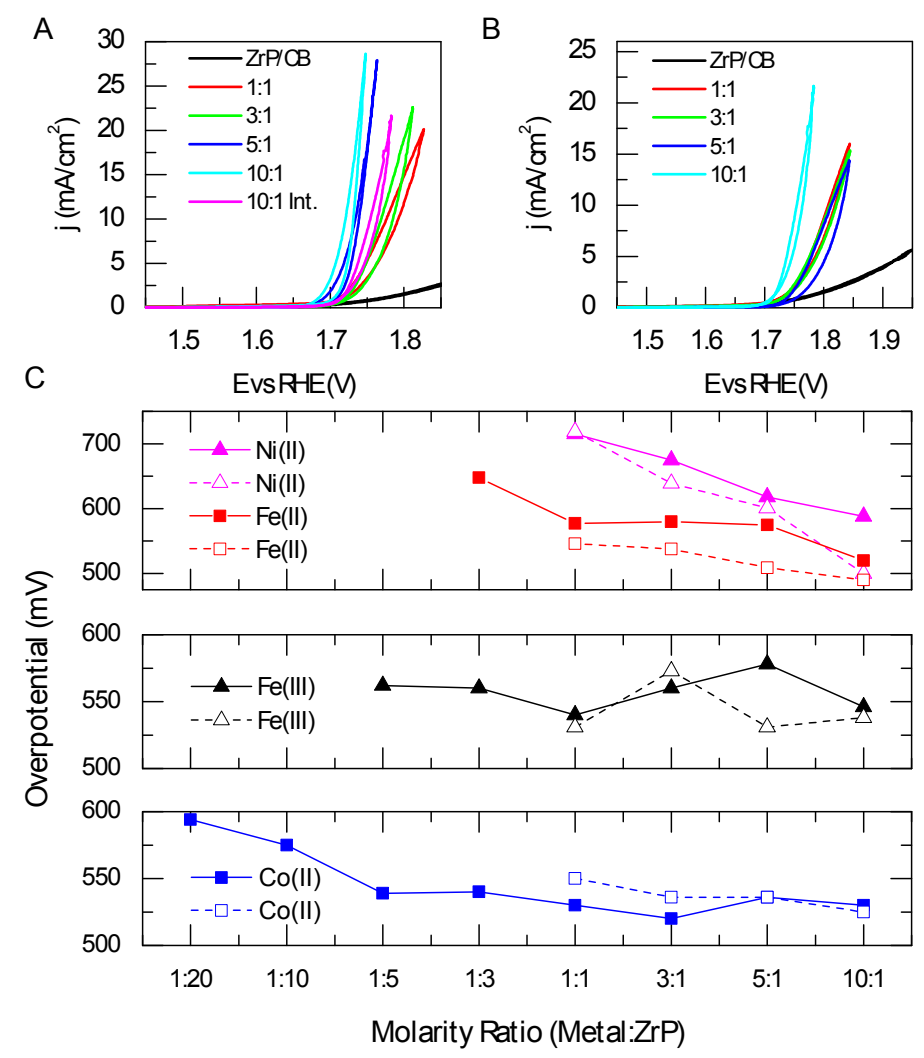

Figure 7. (A) Cyclic voltammograms of adsorbed Fe-ZrP. The best CV for intercalated Fe(II)-ZrP is shown in pink. (B) Cyclic voltammograms of intercalated Fe-ZrP. (C) Electrochemical performance comparison of all four metal systems for adsorbed and intercalated species at $10 \mathrm{~mA} / \mathrm{cm}^{2}$, except for $\mathrm{Ni}(\mathrm{II})$, which was compared at $3 \mathrm{~mA} / \mathrm{cm}^{2}$. Solid and dashed lines represent intercalated and adsorbed metal ZrP systems, respectively

While at this stage the mechanism of OER catalysis remains unclear for either the metal-intercalated $\mathrm{ZrP}$ or the metal-adsorbed $\mathrm{ZrP}$, a further question involves conductivity, as the intercalation of metals within the interlayers could affect the conductivity of the $\mathrm{ZrP}$ nanoparticle [56]. Furthermore, all systems, apart from Ni(II), exhibited diminishing stability with continued cycling (Figure S4). Further work is aimed at enhancing the conductivity of the ZrP supports and tailoring the surface and interlayer properties to improve stability. 


\section{Conclusion}

Our findings indicate that $\mathrm{ZrP}$ can serve as a support for transition metal-based OER catalysts. Increasing the M:ZrP molar ratio had a direct increase in metal content observed by XPS which correlated to an increase in activity for all metal systems. Consequently, as observed by electrochemical cyclic voltammetry, the metal species that were supported within $\mathrm{ZrP}$ required similar, or higher, overpotentials to drive the OER when compared to their metal-adsorbed counterparts. This may result from differences in mass transport and/or electronic conductivity in the two systems. This report on metal-modified ZrP catalysts serves as a basis for developing improved OER catalyst systems, paving the way for future work investigating various metal combinations or molecular species supported onto, or into, $\mathrm{ZrP}$ for enhanced catalytic activity and stability.

\section{Materials and Methods}

\subsection{Materials}

All chemicals were obtained from commercial sources as analytical or reagent grade and used as received. Zirconium oxychloride octahydrate $\left(\mathrm{ZrOCl}_{2} \cdot 8 \mathrm{H}_{2} \mathrm{O}, 98 \%\right)$, iron chloride tetrahydrate $\left(\mathrm{FeCl}_{2} \cdot 4 \mathrm{H}_{2} \mathrm{O}, 98 \%\right)$, iron nitrate nonahydrate $\left(\mathrm{Fe}\left(\mathrm{NO}_{3}\right)_{3} \cdot 9 \mathrm{H}_{2} \mathrm{O}, 98 \%\right)$, cobalt nitrate hexahydrate $\left(\mathrm{Co}\left(\mathrm{NO}_{3}\right)_{2} \cdot 6 \mathrm{H}_{2} \mathrm{O}, 98 \%\right)$, nickel nitrate hexahydrate $\left(\mathrm{Ni}\left(\mathrm{NO}_{3}\right)_{2} \cdot 6 \mathrm{H}_{2} \mathrm{O}, 98.5 \%\right)$, and Nafion ${ }^{\circledR} 117(5 \%)$ were obtained from Sigma-Aldrich (St. Louis, MO, USA). Phosphoric acid $\left(\mathrm{H}_{3} \mathrm{PO}_{4}, 85 \% \mathrm{v} / v\right)$ was obtained from Fisher Scientific (Hampton, NH, USA), glassy carbon rods (SigradurG, HTW Hochtemperatur-Werkstoffe $\mathrm{GmbH}, 5 \mathrm{~mm}$ diameter) were processed by the Stanford University crystal shop to prepare $4 \mathrm{~mm}$ long pieces with the top side polished to a surface root-mean-square (RMS) roughness of less than $50 \mathrm{~nm}$, and carbon black was purchased from Fuel Cell Store (College Station, TX, USA, Vulcan XC-72).

\section{2. $\theta-, \alpha-$, and Metal-Modified ZrP Synthesis}

The synthesis for $\theta-\mathrm{ZrP}$ was the same as reported by Kijima [57]. First, $100 \mathrm{~mL}$ of $6 \mathrm{M} \mathrm{H}_{3} \mathrm{PO}_{4}$ was heated to $94{ }^{\circ} \mathrm{C}$ under constant stirring, followed by the drop-wise addition of $100 \mathrm{~mL}$ of $0.05 \mathrm{M}$ $\mathrm{ZrOCl}_{2} \cdot 8 \mathrm{H}_{2} \mathrm{O}$ aqueous solution. The resulting mixture was refluxed with constant stirring at $94{ }^{\circ} \mathrm{C}$ for two days forming solid $\theta-\mathrm{ZrP}$ particles suspended in aqueous solution. The solution was centrifuged at 10,000 RPM for $20 \mathrm{~min}$, followed by removing the supernatant and then washing the remaining solid with water $(18.2 \mathrm{M} \Omega \cdot \mathrm{cm}$, Merck Millipore, Billerica, MA, USA). This process was repeated three times, resulting in a gelatinous paste material. $\theta-Z r P$ was converted into $\alpha$-ZrP by allowing $\theta-Z r P$ to dry overnight under vacuum at room temperature. $\theta-\mathrm{ZrP}$ was suspended in deionized water at various M:ZrP molar ratios (10:1, 5:1, 3:1, 1:1, 1:3, 1:5, 1:10, and 1:20) with constant stirring at room temperature for five days, producing a metal-intercalated $\mathrm{ZrP}$ catalyst at different loading levels, where " $\mathrm{M}$ " refers to different metal cations studied: $\mathrm{Fe}(\mathrm{II}), \mathrm{Fe}(\mathrm{III}), \mathrm{Co}(\mathrm{II})$, and $\mathrm{Ni}(\mathrm{II})$. Each respective sample was filtered and washed with water three times and set to dry in vacuum overnight. A similar procedure was followed to produce the high molarity (1:1, 3:1, 5:1, and 10:1) ratios for the metal-modified $\alpha$-ZrP with a residence time of one day. The samples were centrifuged and washed, as mentioned above, and all resulting powders were pulverized and sonicated to ease their dispersion in ink solutions.

\subsection{Physical and Chemical Characterization (TEM, FTIR, TGA, XRPD, XPS)}

Transmission electron microscopy (TEM) was performed by a FEI Tecnai (Thermo Fisher Scientific, Inc. (Waltham, MA, USA)) operated at $200 \mathrm{kV}$. Vibrational spectroscopy data was collected from 4000 to $650 \mathrm{~cm}^{-1}$ using a Thermo Fisher Scientific, Inc. (Waltham, MA, USA) Nicolet iS50 FT-IR continuum microscope. Before analysis, the samples were prepared in the following manner: for each sample, a $2 \mu \mathrm{L}$ aqueous suspension was drop-casted onto an International Crystal Laboratories (Garfield, NJ, USA) Real Crystal ${ }^{\circledR}$ KBr IR card. Samples were dried on the IR card with argon gas for ca. 2 min. Thermogravimetric experiments (TGA Q500 TA Instruments, New Castle, DE, USA) were performed 
at a ramp rate of $5^{\circ} \mathrm{C} \mathrm{min}^{-1}$ under a flow of $90 \mathrm{~mL} / \mathrm{min}$ air and $10 \mathrm{~mL} / \mathrm{min}$ nitrogen up to $1000{ }^{\circ} \mathrm{C}$. The lattice spacing and crystallinity of the catalysts were investigated using $\mathrm{X}$-ray powder diffraction (Philips PANanalytical, Almelo, The Netherlands, $X^{\prime}$ Pert Pro) with Cu K $\alpha$ radiation $(\lambda=1.54184 \AA$ ). The interlayer distance of the intercalated products was obtained from Bragg's Law $\left(n \lambda=2 \mathrm{~d}_{\mathrm{hkl}} \sin \theta\right)$ using the angle at which the first-order diffraction peak appears in the diffractograms, where $\lambda$ is the wavelength of the $X$-ray source, $d_{h k l}$ is the interlayer distance between planes in the unit cell and $\theta$ is the diffraction angle. The chemical state and atomic concentration of $\mathrm{M}$ and $\mathrm{Zr}$ were examined using high-resolution XPS (PHI 5000 VersaProbe, Physical Electronics, Enzo, Chigasaki, Japan) with an Al $\mathrm{K} \alpha$ source. All spectra were calibrated to the adventitious carbon $1 \mathrm{~s}$ peak at $284.8 \mathrm{eV}$ and fitted using a Shirley background and constraints for doublets, such as full width at half maximum, peak areas, and peak splitting, were taken into consideration for each respective transition metal and nonmetal. Atomic concentrations were calculated using the relative peak area ratio of the $\mathrm{Zr} 3 \mathrm{~d}$ peak and the metal $2 p$ peak. Assuming a Poisson distribution for the noise in the data, the pooled standard deviation for each peak area which were converted to atomic concentrations were calculated by implementing a Monte Carlo simulation through CasaXPS (Casa Software Ltd., Teignmouth, Devon, UK).

\subsection{Ink Preparation and Electrochemical Measurements}

Each catalyst ink was prepared by dispersing $2.5 \mathrm{mg}$ of carbon black (Vulcan XC-72, Fuel Cell Store, College Station, TX, USA) and $5 \mathrm{mg}$ of metal-modified ZrP catalyst into $1.53 \mathrm{~mL}$ of water, $1.02 \mathrm{~mL}$ of isopropanol, and $10.02 \mu \mathrm{L}$ of Nafion 117. Carbon black was added to create a conductive surface since $\mathrm{ZrP}$ is not very conductive by itself. The resulting ink was sonicated for $60 \mathrm{~min}$, or longer, until it was well dispersed. Each catalyst sample was produced by placing a clean, mirror finish-polished, $5 \mathrm{~mm}$ diameter glassy carbon disk into a Teflon holder and mounted into an RDE apparatus (Pine Research Instrumentation, Durham, NC, USA). The RDE was inverted and $10 \mu \mathrm{L}$ of catalyst ink was drop-cast onto the disk which was then rotated at 600 RPM for 20-30 min until the catalyst ink dried. The metal-ZrP loading on the $0.196 \mathrm{~cm}^{2}$ disk was $0.1 \mathrm{mg} / \mathrm{cm}^{2}$.

The OER activity of the metal-modified ZrP-based catalyst was examined using a three-electrode RDE setup. The working electrode was composed of a thin coating of catalyst on a glassy carbon disk, prepared as described above, a Pt wire counter electrode, and an $\mathrm{Ag} / \mathrm{AgCl}$ reference electrode. The OER activity was determined by cycling the potential between 1.1 and $1.8 \mathrm{~V}$ versus the reversible hydrogen electrode (RHE) at $20 \mathrm{mVs}^{-1}$ in $\mathrm{O}_{2}$-saturated $0.1 \mathrm{M} \mathrm{KOH}$ electrolyte and an electrode rotation speed of 1600 RPM. The scan rate was slow enough to ensure steady-state behavior at the electrode surface and the rotation speed was fast enough to help in product removal from the surface and limit the bubble formation from oxygen evolution. The solution resistance of the cell was measured at $100 \mathrm{kHz}$ and ohmic correction occurred after testing. The typical measured solution resistance was $\sim 45 \Omega$.

Supplementary Materials: The following are available online at www.mdpi.com/2073-4344/7/5/132/s1, Figure S1: FTIR spectra for adsorbed Fe(III) at a 10:1 M:ZrP ratio; Figure S2: XRPD patterns for Fe(II), Fe(III), $\mathrm{Co}(\mathrm{II})$, and $\mathrm{Ni}$ (II)-intercalated $\mathrm{ZrP}$ at (from top to bottom) 10:1, 5:1, 3:1, 1:1, 1:3, 1:5, 1:10, and 1:20 M:ZrP molar ratios. The bottom diffraction pattern in all frames is that of pure $\alpha$-ZrP; Figure S3: XRPD patterns for Fe(II), $\mathrm{Fe}(\mathrm{III}), \mathrm{Co}(\mathrm{II})$, and Ni(II)-adsorbed ZrP systems at (from top to bottom) 10:1, 5:1, 3:1, and 1:1 M:ZrP molar ratios. The bottom diffraction pattern in all frames is that of pure $\alpha-Z r P$; Figure S4: Cyclic voltammograms of adsorbed $\mathrm{Fe}(\mathrm{II}), \mathrm{Fe}(\mathrm{III}), \mathrm{Co}(\mathrm{II})$, and $\mathrm{Ni}(\mathrm{II})-\mathrm{ZrP}$ systems. The best intercalated 10:1 M:ZrP CV is shown in pink. Dashed lines represent cyclic voltammograms after 20 cycles.

Acknowledgments: This work was supported by the NSF under NSF Center for Chemical Innovation CHE-1305124 for Solar Fuels. J.S. was supported by the Department of Defense (DoD) through the National Defense Science and Engineering Graduate Fellowship (NDSEG) Program. Part of this work was performed at the Stanford Nano Shared Facilities (SNSF), supported by the National Science Foundation under award ECCS-1542152. The authors would like to acknowledge Alaina L. Strickler for the TEM micrographs and the Molecular Sciences Research Center of the University of Puerto Rico.

Author Contributions: T.F.J., J.L.C., M.V.R.-G., and J.S. conceived and designed the experiments; J.S. and M.V.R.-G. performed the experiments; J.S., I.N., and M.V.R.-G. analyzed the data; and all authors contributed in writing the paper. 
Conflicts of Interest: The authors declare no conflict of interest.

\section{References}

1. Ursua, A.; Gandia, L.M.; Sanchis, P. Hydrogen production from water electrolysis: Current status and future trends. Proc. IEEE 2012, 100, 410-426. [CrossRef]

2. Gahleitner, G. Hydrogen from renewable electricity: An international review of power-to-gas pilot plants for stationary applications. Int. J. Hydrogen Energy 2013, 38, 2039-2061. [CrossRef]

3. Ehteshami, S.M.M.; Chan, S.H. The role of hydrogen and fuel cells to store renewable energy in the future energy network-Potentials and challenges. Energy Policy 2014, 73, 103-109. [CrossRef]

4. Lewis, N.S.; Nocera, D.G. Powering the planet: Chemical challenges in solar energy utilization. Proc. Natl. Acad. Sci. USA 2006, 103, 15729-15735. [CrossRef] [PubMed]

5. Gray, H.B. Powering the planet with solar fuel. Nat. Chem. 2009, 1, 7. [CrossRef] [PubMed]

6. Thomsen, J.M.; Huang, D.L.; Crabtree, R.H.; Brudvig, G.W. Iridium-based complexes for water oxidation. Dalton Trans. 2015, 44, 12452-12472. [CrossRef] [PubMed]

7. Browne, M.P.; Nolan, H.; Duesberg, G.S.; Colavita, P.E.; Lyons, M.E. G. Low-overpotential high-activity mixed manganese and ruthenium oxide electrocatalysts for oxygen evolution reaction in alkaline media. ACS Catal. 2016, 6, 2408-2415. [CrossRef]

8. Enman, L.J.; Burke, M.S.; Batchellor, A.S.; Boettcher, S.W. Effects of intentionally incorporated metal cations on the oxygen evolution electrocatalytic activity of nickel (oxy)hydroxide in alkaline media. ACS Catal. 2016, 6, 2416-2423. [CrossRef]

9. Burke, M.S.; Enman, L.J.; Batchellor, A.S.; Zou, S.; Boettcher, S.W. Oxygen evolution reaction electrocatalysis on transition metal oxides and (oxy)hydroxides: Activity trends and design principles. Chem. Mater. 2015, 27, 7549-7558. [CrossRef]

10. Burke, M.S.; Kast, M.G.; Trotochaud, L.; Smith, A.M.; Boettcher, S.W. Cobalt-iron (oxy)hydroxide oxygen evolution electrocatalysts: The role of structure and composition on activity, stability, and mechanism. J. Am. Chem. Soc. 2015, 137, 3638-3648. [CrossRef] [PubMed]

11. Galán-Mascarós, J.R. Water oxidation at electrodes modified with earth-abundant transition-metal catalysts. ChemElectroChem 2015, 2, 37-50. [CrossRef]

12. Antolini, E. Iridium as catalyst and cocatalyst for oxygen evolution/reduction in acidic polymer electrolyte membrane electrolyzers and fuel cells. ACS Catal. 2014, 4, 1426-1440. [CrossRef]

13. Fabbri, E.; Habereder, A.; Waltar, K.; Kötz, R.; Schmidt, T.J. Developments and perspectives of oxide-based catalysts for the oxygen evolution reaction. Catal. Sci. Technol. 2014, 4, 3800-3821. [CrossRef]

14. Suntivich, J.; May, K.J.; Gasteiger, H.A.; Goodenough, J.B.; Shao-Horn, Y. A Perovskite oxide optimized for oxygen evolution catalysis from molecular orbital principles. Science 2011, 334, 1383-1385. [CrossRef] [PubMed]

15. McCrory, C.C.L.; Jung, S.; Ferrer, I.M.; Chatman, S.M.; Peters, J.C.; Jaramillo, T.F. Benchmarking hydrogen evolving reaction and oxygen evolving reaction electrocatalysts for solar water splitting devices. J. Am. Chem. Soc. 2015, 137, 4347-4357. [CrossRef] [PubMed]

16. Man, I.C.; Su, H.-Y.; Calle-Vallejo, F.; Hansen, H.A.; Martínez, J.I.; Inoglu, N.G.; Kitchin, J.; Jaramillo, T.F.; Nørskov, J.K.; Rossmeisl, J. Universality in oxygen evolution electrocatalysis on oxide surfaces. ChemCatChem 2011, 3, 1159-1165. [CrossRef]

17. Weng, B.; Xu, F.; Wang, C.; Meng, W.; Grice, C.R.; Yan, Y. A layered $\mathrm{Na}_{1-x} \mathrm{Ni}_{y} \mathrm{Fe}_{1-y} \mathrm{O}_{2}$ double oxide oxygen evolution reaction electrocatalyst for highly efficient water-splitting. Energy Environ. Sci. 2017, 10, 121-128. [CrossRef]

18. Lu, Z.; Wang, H.; Kong, D.; Yan, K.; Hsu, P.-C.; Zheng, G.; Yao, H.; Liang, Z.; Sun, X.; Cui, Y. Electrochemical tuning of layered lithium transition metal oxides for improvement of oxygen evolution reaction. Nat. Commun. 2014, 5, 4345. [CrossRef] [PubMed]

19. Doyle, A.D.; Montoya, J.H.; Vojvodic, A. Improving oxygen electrochemistry through nanoscopic confinement. Chem CatChem 2015, 7, 738-742. [CrossRef]

20. Oh, H.-S.; Nong, H.N.; Reier, T.; Bergmann, A.; Gliech, M.; Ferreira de Araújo, J.; Willinger, E.; Schlögl, R.; Teschner, D.; Strasser, P. Electrochemical catalyst-support effects and their stabilizing role for $\operatorname{IrO}_{x}$ 
nanoparticle catalysts during the oxygen evolution reaction. J. Am. Chem. Soc. 2016, 138, 12552-12563. [CrossRef] [PubMed]

21. Wei Seh, Z.; Kibsgaard, J.; Dickens, C.F.; Chorkendorff, I.; Nørskov, J.K.; Jaramillo, T.F. Combining theory and experiment in electrocatalysis: Insights into materials design. Science 2017, 355. [CrossRef]

22. Wu, Z.-S.; Yang, S.; Sun, Y.; Parvez, K.; Feng, X.; Müllen, K. 3D Nitrogen-doped graphene aerogel-supported $\mathrm{Fe}_{3} \mathrm{O}_{4}$ nanoparticles as efficient electrocatalysts for the oxygen reduction reaction. J. Am. Chem. Soc. 2012, 134, 9082-9085. [CrossRef] [PubMed]

23. Kou, R.; Shao, Y.; Wang, D.; Engelhard, M.H.; Kwak, J.H.; Wang, J.; Viswanathan, V.V.; Wang, C.; Lin, Y.; Wang, Y.; et al. Enhanced activity and stability of Pt catalysts on functionalized graphene sheets for electrocatalytic oxygen reduction. Electrochem. Commun. 2009, 11, 954-957. [CrossRef]

24. Ma, T.Y.; Dai, S.; Jaroniec, M.; Qiao, S.Z. Graphitic carbon nitride nanosheet-carbon nanotube three-dimensional porous composites as high-performance oxygen evolution electrocatalysts. Angew. Chem. Int. Ed. 2014, 53, 7281-7285. [CrossRef] [PubMed]

25. Troup, J.M.; Clearfield, A. On mechanism of ion exchange in zirconium phosphates. 20. Refinement of the crystal structure of $\alpha$-zirconium phosphate. Inorg. Chem. 1977, 16, 3311-3314. [CrossRef]

26. Alberti, G.; Costantino, U.; Gupta, J.P. Crystalline insoluble acid salts of tetravalent metals-XIX: $\mathrm{Na}^{+}$-catalyzed $\mathrm{H}^{+}-\mathrm{Mg}^{2+}$ and $\mathrm{H}_{+}-\mathrm{Cs}^{2+}$ ion exchanges on $\alpha$-zirconium phosphate. J. Inorg. Nucl. Chem. 1974, 36, 2109-2114. [CrossRef]

27. Alberti, G.; Bertrami, R.; Costantino, U. Crystalline insoluble acid salts of tetravalent metals-XXII: Effect of small amounts of $\mathrm{Na}+$ on the ion exchange of alkaline earth metal ions on crystalline $\mathrm{Zr}\left(\mathrm{HPO}_{4}\right)_{2} \cdot \mathrm{H}_{2} \mathrm{O}$. J. Inorg. Nucl. Chem. 1976, 38, 1729-1732. [CrossRef]

28. Alberti, G.; Costantino, U. Recent progress in the intercalation chemistry of layered $\alpha$-zirconium phosphate and its derivatives, and future perspectives for their use in catalysis. J. Mol. Catal. 1984, 27, 235-250. [CrossRef]

29. Marti, A.; Colón, J.L. Direct ion exchange of tris(2,2'-bipyridine)ruthenium(II) into an $\alpha$-zirconium phosphate framework. Inorg. Chem. 2003, 42, 2830-2832. [CrossRef] [PubMed]

30. Alberti, G.; Costantino, U.; Gill, J.S. Crystalline insoluble acid salts of tetravalent metals—XXIII: Preparation and main ion exchange properties of highly hydrated zirconium bis monohydrogen orthophosphates. J. Inorg. Nucl. Chem. 1976, 38, 1733-1738. [CrossRef]

31. Atienzar, P.; Victoria-Rodríguez, M.; Juanes, O.; Rodríguez-Ubis, J.C.; Brunet, E.; García, H. Layered $\gamma$-zirconium phosphate as novel semiconductor for dye-sensitized solar cells: Improvement of photovoltaic efficiency by intercalation of a ruthenium complex-viologen dyad. Energy Environ. Sci. 2011, 4, 4718-4726. [CrossRef]

32. Santiago, M.B.; Declet-Flores, C.; Díaz, A.; Vélez, M.M.; Zoé-Bosques, M.; Sanakis, Y.; Colón, J.L. Layered inorganic materials as redox agents: Ferrocenium-intercalated zirconium phosphate. Langmuir 2007, 23, 7810-7817. [CrossRef] [PubMed]

33. Santiago, M.B.; Daniel, G.A.; David, A.; Casañas, B.; Hernández, G.; Guadalupe, A.R.; Colón, J.L. Effect of enzyme and cofactor immobilization on the response of ethanol oxidation in zirconium phosphate modified biosensors. Electroanalysis 2010, 22, 1097-1105. [CrossRef]

34. Rivera, E.J.; Barbosa, C.; Torres, R.; Grove, L.; Taylor, S.; Connick, W.B.; Clearfield, A.; Colón, J.L. Vapochromic and vapoluminescent response of materials based on platinum(ii) complexes intercalated into layered zirconium phosphate. J. Mater. Chem. 2011, 21, 15899-15902. [CrossRef]

35. Díaz, A.; Saxena, V.; González, J.; David, A.; Casañas, B.; Carpenter, C.; Batteas, J.D.; Colón, J.L.; Clearfield, A.; Hussain, M.D. Zirconium phosphate nanoplatelets: A novel platform for drug delivery in cancer therapy. Chem. Commun. 2012, 48, 1754-1756. [CrossRef] [PubMed]

36. Horsley, S.E.; Nowell, D.V.; Stewart, D.T. The infrared and Raman spectra of $\alpha$-zirconium phosphate. Spectrochim. Acta Part A Mol. Spectrosc. 1974, 30, 535-541. [CrossRef]

37. Mosby, B.M.; Díaz, A.; Bakhmutov, V.; Clearfield, A. Surface functionalization of zirconium phosphate nanoplatelets for the design of polymer fillers. ACS Appl. Mater. Interfaces 2014, 6, 585-592. [CrossRef] [PubMed]

38. Szirtes, L.; Szeleczky, A.M.; Rajeh, A.O.; Kuzmann, E. Thermal behaviour of transition metal-containing zirconium phosphate. J. Therm. Anal. Calorim. 1999, 56, 447-451. [CrossRef] 
39. Alberti, G.; Casciola, M.; Costantino, U.; Vivani, R. Layered and pillared metal(IV) phosphates and phosphonates. Adv. Mater. 1996, 8, 291-303. [CrossRef]

40. Alagna, L.; Prosperi, T.; Tomlinson, A.A.G.; Ferragina, C.; La Ginestra, A. Extended X-ray absorption fine structure investigation of local symmetry changes in $\mathrm{Co}^{2+}$ - and $\mathrm{Ni}^{2+}$-exchanged zirconium phosphates. J. Chem. Soc. Faraday Trans. 1 Phys. Chem. Condens. Ph. 1983, 79, 1039-1047. [CrossRef]

41. Alagna, L.; Tomlinson, A.A.G.; Ferragina, C.; La Ginestra, A. Zirconium phosphates partially exchanged with transition-metal ions: Characterisation and stereochemical changes induced by heat treatment. J. Chem. Soc. Dalton Trans. 1981, 2376-2384. [CrossRef]

42. Mani, B.; de Neufville, J.P. Dehydration of chemically and electrochemically impregnated (CI and EI) nickel hydroxide electrodes. J. Electrochem. Soc. 1988, 135, 800-803. [CrossRef]

43. Miessler, G.L.; Fischer, P.J.; Tarr, D.A. Inorganic Chemistry, 5th ed.; Pearson Education: London, UK, 2014; pp. 374-377.

44. Casañas-Montes, B.; Díaz, A.; Barbosa, C.; Ramos, C.; Collazo, C.; Meléndez, E.; Queffelec, C.; Fayon, F.; Clearfield, A.; Bujoli, B.; et al. Molybdocene dichloride intercalation into zirconium phosphate nanoparticles. J. Organomet. Chem. 2015, 791, 34-40. [CrossRef]

45. Sun, L.; Boo, W.J.; Sue, H.-J.; Clearfield, A. Preparation of $\alpha$-zirconium phosphate nanoplatelets with wide variations in aspect ratios. New J. Chem. 2007, 31, 39-43. [CrossRef]

46. Costantino, U.; Szirtes, L.; Kuzmann, E.; Megyeri, J.; Lázár, K. Exchange of iron ions into layers of $\alpha$-zirconium phosphate. Solid State Ion. 2001, 141, 359-364. [CrossRef]

47. Yamashita, T.; Hayes, P. Analysis of XPS spectra of $\mathrm{Fe}^{2+}$ and $\mathrm{Fe}^{3+}$ ions in oxide materials. Appl. Surf. Sci. 2008, 254, 2441-2449. [CrossRef]

48. Nemoshkalenko, V.V.; Didyk, V.V.; Krivitskii, V.P.; Senekevich, A.I. Investigation of the atomic charges in iron, cobalt and nickel phosphides. Zhurnal Neorganicheskoi Khimii 1983, 28, 2182-2192.

49. Hernández-Huesca, R.; Braos-García, P.; Mérida-Robles, J.; Maireles-Torres, P.; Rodríguez-Castellón, E.; Jiménez-López, A. Cobalt-based alumina pillared zirconium phosphate catalysts for the selective catalytic reduction of NO by propane. Chemosphere 2002, 48, 467-474. [CrossRef]

50. Nardi, K.L.; Yang, N.; Dickens, C.F.; Strickler, A.L.; Bent, S.F. Creating highly active atomic layer deposited $\mathrm{NiO}$ electrocatalysts for the oxygen evolution reaction. Adv. Energy Mater. 2015, 5, 1500412. [CrossRef]

51. Cheikhi, N.; Ziyad, M. Methane conversion to higher alkanes over ruthenium and cobalt loaded $\mathrm{Zr}_{3}\left(\mathrm{PO}_{4}\right)_{4}$. J. Phys. IV 2005, 123, 301-305. [CrossRef]

52. Zhan, Y.; Lu, M.; Yang, S.; Liu, Z.; Lee, J.Y. The origin of catalytic activity of nickel phosphate for oxygen evolution in alkaline solution and its further enhancement by iron substitution. ChemElectroChem 2016, 3, 615-621. [CrossRef]

53. Colón, J.L.; Thakur, D.S.; Yang, C.-Y.; Clearfield, A.; Martin, C.R. X-ray photoelectron spectroscopy and catalytic activity of $\alpha$-zirconium phosphate and zirconium phosphate sulfophenylphosphonate. J. Catal. 1990, 124, 148-159. [CrossRef]

54. Arfelli, M.; Mattogno, G.; Ferragina, C.; Massucci, M.A. XPS characterization of $\gamma$-zirconium phosphate and of some of its intercalation compounds. A comparison with the $\alpha$-zirconium phosphate analogues. J. Incl. Phenom. Mol. Recognit. Chem. 1991, 11, 15-27. [CrossRef]

55. Xie, J.; Wang, R.; Bao, J.; Zhang, X.; Zhang, H.; Li, S.; Xie, Y. Zirconium trisulfide ultrathin nanosheets as efficient catalysts for water oxidation in both alkaline and neutral solutions. Inorg. Chem. Front. 2014, 1, 751-756. [CrossRef]

56. Szirtes, L.; Megyeri, J.; Kuzmann, E.; Klencsár, Z. Electrical conductivity of transition metal containing crystalline zirconium phosphate materials. Solid State Ion. 2001, 145, 257-260. [CrossRef]

57. Kijima, T. Direct preparation of $\theta$-zirconium phosphate. Bull. Chem. Soc. Jpn. 1982, 55, 3031-3032. [CrossRef]

(C) 2017 by the authors. Licensee MDPI, Basel, Switzerland. This article is an open access article distributed under the terms and conditions of the Creative Commons Attribution (CC BY) license (http:/ / creativecommons.org/licenses/by/4.0/). 